\author{
Riccardo POLONI*
}

\title{
Nacerdes (Xanthochroa) carniolica peloponesiaca Švihla, 1991 (Coleoptera: Oedemeridae) in Italy: the first case of trans-Adriatic false blister beetle with considerations on Nacerdes (Xanthochroa) carniolica (Gistl, 1834)
}

\begin{abstract}
Riassunto: Nacerdes (Xanthochroa) carniolica peloponesiaca Švihla, 1991 (Coleoptera: Oedemeridae) in Italia: primo caso di Oedemeridae transadriatico con considerazioni su Nacerdes (Xanthochroa) carniolica (Gistl, 1834)

Viene qui presentata la prima popolazione italiana di Nacerdes (Xanthochroa) carniolica peloponesiaca Švihla, 1991 e viene discussa la sua origine biogeografica date le attuali conoscenze sui Coleotteri a distribuzione transadriatica. L'areale di questa sottospecie viene rivisto e vengono fornite alcune note biologiche sulle preferenze alimentari della larva e sull'ecologia.

Abstract: Nacerdes (Xanthochroa) carniolica peloponesiaca Švihla, 1991 is recorded in Italy for the first time and the biogeographical origin of this new population is discussed on the base of the current knowledge on Coleoptera with trans-Adriatic distribution. The range of this subspecies is revised and some biological notes on the larval food preferences and ecology are provided.
\end{abstract}

Key words: Tenebrionoidea, biogeography, population, Nacerdini, trans-Adriatic, Greece.

\section{INTRODUCTION}

Nacerdes (Xanthochroa) carniolica Gistel, 1834 is a polytypic species widely distributed through Western and Central Palaearctic Region, ranging from Spain to Georgia (Švihla, in: Löbl \& Smetana, 2008). The species counts, after the nominotypical, three other subspecies: $N$. (X.) carniolica atlantica Allemand, 1993 occurring in Northern Spain and South-Western France, N. (X.) carniolica peloponesiaca Švihla, 1991 in Southern Greece and Crete, $N$. (X.) carniolica foveata Fairmaire, 1892 in Southern Turkey; the nominotypical subspecies occurs in the rest of the range (Švihla in Löbl \& Smetana, 2008; Švihla, 1997; Brustel \& Kakiopoulos, 2009; Vásquez \& Recalde, 2003).

In Italy, the only recorded subspecies was so far the nominotypical one, considered as occurring only in Northern Italy by Bologna (1995) and in the Alps by Vasquez (2002); Pezzi \& Bendazzi (2010) reported this taxon in the Northern Apennines (Emilia Romagna region) and Bologna (2016) in Central and Southern Apennines (Calabria region) extending thus the Italian range of this species to the whole Apennines chain.

In this paper the author presents the first population of $N$. (X.) carniolica peloponesiaca in Calabria. This new record represents a relevant biogeographic novelty for the Italian fauna and confirms that Southern Apennines are a hot spot of biodiversity that requires further investigation. A distribution map of $N$. carniolica peloponesiaca is represented in Fig. 1.

\section{MATERIALS AND METHODS}

Specimens were observed with an Optech SZ$\mathrm{N}$ microscope, and photographs were taken with a Nikon D7100 camera and a Sigma 105mm F2.8 EX DG OS HSM Macro lens with a Manfrotto 055 tripod and continuous lighting.

The following abbreviations used in the text represent the studied collections:

RPPC $=$ Riccardo Poloni personal collection, Formigine, Italy;

XVPC = Xavier Vasquez Albalate personal collection, Terrassa, Spain;

MBC = Marco Alberto Bologna collection, Roma Tre University, Rome, Italy;

$\mathrm{NMPC}=$ National Museum, Prague, Czech Republic.

The locality data are reported as written on the label; the identification label is also reported.

Material eXAmined. $N$. (X.) carniolica peloponesiaca: 16 exx., Calabria (Reggio Calabria prov.), Stilo,

${ }^{*}$ Riccardo Poloni, Via P. Togliatti 16, 41043 Formigine (MO), Italy. Email: riccardo.poloni@gmail.com 
loc. Morzu $1200 \mathrm{~m}, 38^{\circ} 29^{\prime} \mathrm{N} 16^{\circ} 22^{\prime} \mathrm{E}$, 3.VI22.VII.2017, wine traps, L. Arcorace legit, R. Poloni det. 2018 (RPPC); 4 exx. ibidem (MBPC), 26 exx., Calabria (Reggio Calabria prov.), Villaggio Ziia, 1000m, 7.VI-15.VII.2018, wine traps, L. Arcorace legit, R. Poloni det. 2018 (RPPC); 2 exx. ibidem (NMPC); 1 male, GR Eubea, Stropones 1000m, $23^{\circ} 53 \mathrm{E} 38^{\circ} 35 \mathrm{~N}, 7 . \mathrm{VIII} .1983$, M. Malicky (NMPC); 2 male paratypes, Griechenland, Taygetos $1300 \mathrm{~m}, 10$ km W Trapezonti, 16.8.79, F. et J. Hüttinger leg., V. Švihla det. 1989 (NMPC); 1 female, Graecia, Peloponnesos, Pournarókastro p. Patra env., bushy pastures, $800 \mathrm{~m}$ a.s.1., 16.vi.2003, S. Benedikt leg. (NMPC); 1 female, Kreta Griechl., 7 km S Anovlasia $1000 \mathrm{~m}, 21^{\circ} 53 \mathrm{E} / 37^{\circ} 58 \mathrm{E}$ (probably the coordinates are wrong and must be interpreted as $21^{\circ} 53^{\prime} \mathrm{E} 37^{\circ} 58^{\prime} \mathrm{N}$ ), 31.VII.91, H. Malicky (NMPC).

N. (X.) carniolica foveata: 1 male Anatolia,
Kilik. Taurus, Vill. Mersin, Namrun 29.5-6.6.1979, 1200 m, leg. F. Holzschuh u. F. Resel, V. Švihla det. 1991 (NMPC); 1 male Bürücek, Toros, Anat. 29-31.7.47 Exp. N. Mus. ČSR., V. Švihla det. 2004 (NMPC).

$N$. (X.) carniolica atlantica: 1 female paratype, env. de Bordeaux, Gradignan, 19.7.73 G. Tempère, ex coll. R. Constantin, R. Allemand det. 92 (XVPC)

$N$. (X.) carniolica carniolica: many exx. from different localities of Italy, Southern and Central Europe.

DiAgNostic CHARACTERS. Nacerdes (Xanthochroa) carniolica peloponesiaca Svihla, 1991 differs from the nominotypical subspecies by the yellowish-brown elytra with only lateral sides up to $2 / 3$ dark brown (Švihla, 1991). The specimens from Calabria match perfectly with the description of the Greek subspecies and with the examined paratypes. A comparison be-

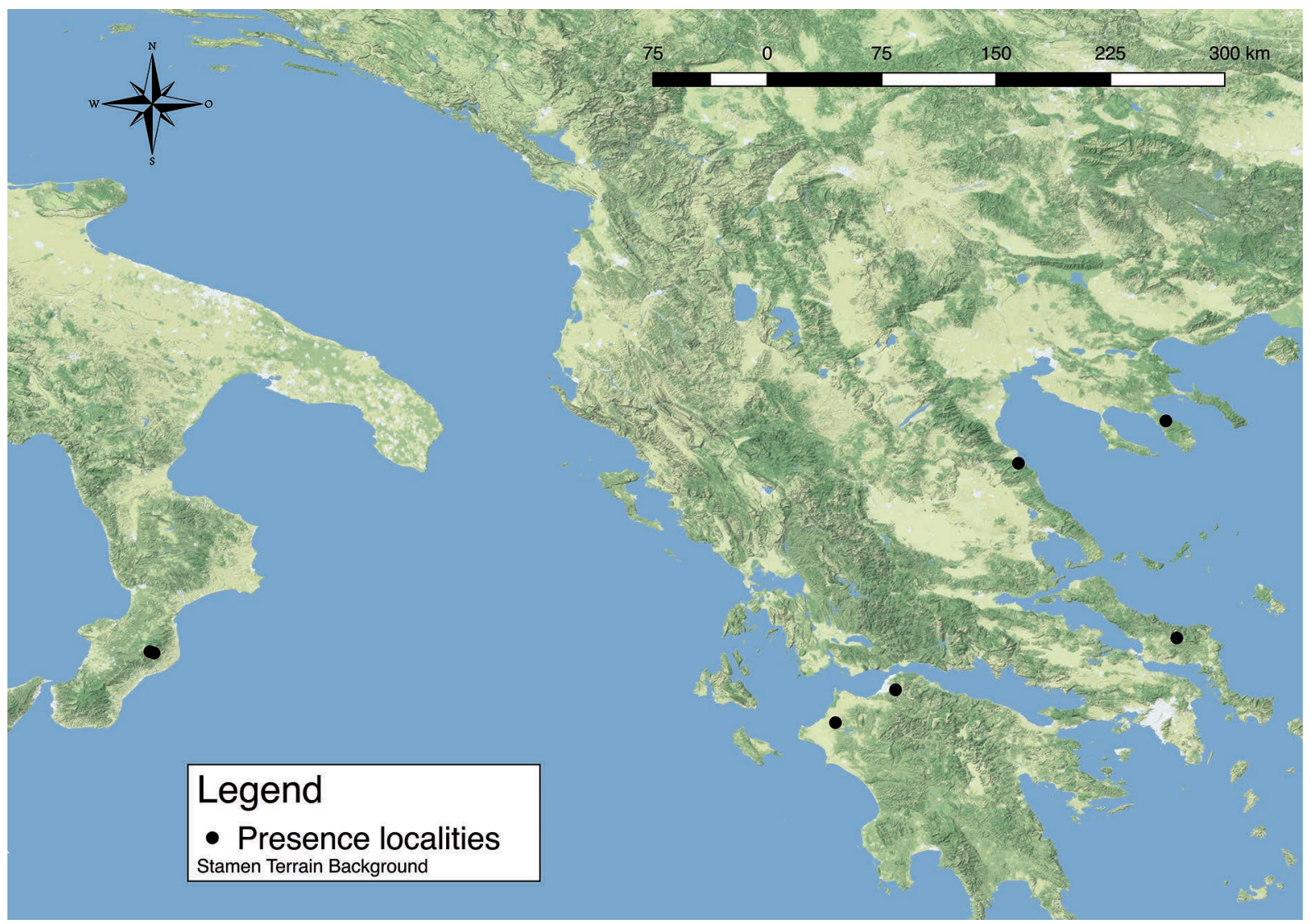

Fig. 1. Presence localities of Nacerdes carniolica peloponesiaca. 
tween the paratypes and the specimens from Calabria is shown in Fig. 2.

ECOlOGiCAL NOTES. The specimens from Calabria were all collected using wine traps placed on tree branches in June and July. The biotope is a relict beech forest, belonging to the Appennine Fagus sylvatica L. forest with Taxus baccata L. and Ilex aquifolium L. (41.181 PAL. CLASS), with extended old forests that are the ideal habitat for this species.

Vasquez (2002) considers Nacerdes (Xanthochroa) carniolica feeding at the larval stage in rotten wood of Pinus and Abies; in Italy though this species regularly develops in broad-leaf wood. The colleague Raffaele Bocchini (pers. comm.) has reared this species from a dead and damp branch of Acer sp. collected in Santa Sofia (FC); the author collected several specimens of $N$. carniolica carniolica using wine traps in two localities: Vologno, Secchia river (RE) and Torre Maina (MO), in oak/hornbeam forests without conifers, suggesting that this species is associated in Apennines hills at low altitude with oak or hornbeam. Finally, Carlo Massarone, another Italian colleague, collected this species using wine traps in San

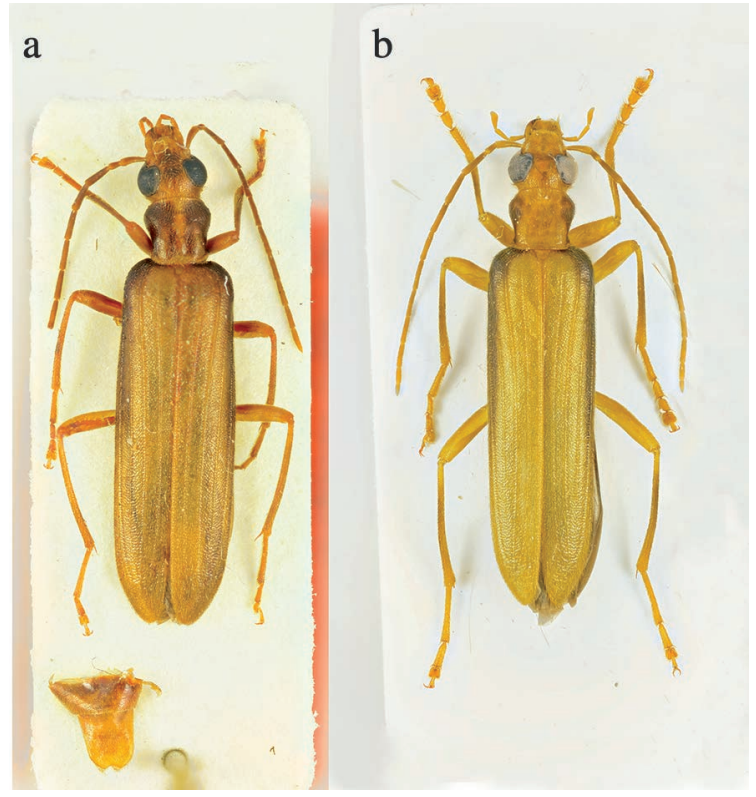

Fig. 2. Habitus of Nacerdes carniolica peloponesiaca, paratype from Greece (a) and specimen from Calabria (b).
Godenzo (FI) in beech forests (pers. comm.). These observations suggest that this species is associated with rotten wood of both broad-leaf trees and conifers.

BiogeOgRAPHICAL REMARKS. In 1950 Gridelli published his milestone paper "Il problema delle specie a diffusione transadriatica con particolare riguardo ai Coleotteri" (The problem of species with trans-Adriatical distribution with particular regard on Coleoptera") that is still one of the major contributions to the Italian Biogeography. In this paper Gridelli explained how and why the same species or sister species can be observed in the Balkans and in Adriatic side of Italy or Southern Italy giving examples of species with this distribution called "trans-Adriatic". These species share a disjunct distribution in the lands on both sides of Adriatic Sea originated by dispersion and afterwards separated by vicariance events. Gridelli (1950) distinguished two categories of species with trans-Adriatic chorotype: (a) those that have crossed the Adriatic Sea in the Pliocene when the sea level variation uncovered large portions of land and (b) the palaeo-Egeic species that have colonized Italy during the Miocene, when the Adriatic Sea was not yet in the present collocation.

The first group of species do not present differentiated populations due to the recent dispersal, besides the second and more ancient group of species has several evolved differentiated populations at a subspecies or species level.

After the Gridelli's paper several other species with a trans-Adriatic distribution were identified making Southern Italy an unanimously considered hotspot of biodiversity (Osella \& Magnano, 1986). Among Coleoptera with trans-Adriatic distribution we can cite Euzonitis fulvipennis (Fabricius, 1792) (Meloidae), Buprestis (Cypriacis) splendens splendens Fabricius, 1775 (Buprestidae), Neodorcadion bilineatum (Germar, 1824) (Cerambycidae) (Bologna, pers. comm.; Curletti, 2005; Sama \& Löbl, 2010).

On the base of available informations I suppose that the origin of the Italian population of $\mathrm{Nac}$ erdes (Xanthochroa) carniolica peloponesiaca should be explained by a dispersal event from Greece to Italy during the Pliocene from Greece to Calabria with the establishing there of a secondary population. The Italian population could consequently be considered a true trans-Adriatic element sensu Gridelli (1950). It's quite strange though that a few kilometers away from 
Stilo were recently found some specimens belonging to the nominotypical subspecies reported by Bologna (2016). Probably the population of $N$. (X.) carniolica peloponesiaca occurs as a relict in a small area and the spread of the nominotypical subspecies occurred in another more recent period such as a Pleistocenic glacial phase. Interestingly, now in Calabria relict populations of both subspecies with distinct origin occur in very close localities.

\section{AKNOWLEDGEMENTS}

I am very grateful to many colleagues that supported me with material and advices: Luciano Arcorace, who collected all the specimens, Marco Bologna and Xavier Vasquez Albalate for their advices about the manuscript, Marik Cocchi for his comments on Apennines Geology, Lukas Sekerka for the loan of paratypes of $N$. (X.) carniolica peloponesiaca deposited in National Museum, Prague.

\section{REFERENCES}

Bologna M.A., 1995 - Famiglia Oedemeridae. In: Angelini F., Audisio P., Bologna M.A., De Biase A., $\quad$ Franciscolo M.E., Nardi G., RatTi E., ZampetTi M.F., Coleoptera Polyphaga XII (Heteromera escl. Lagriidae, Alleculidae, Tenebrionidae), pp. 1-30. In: Minelli A., Ruffo S., La Posta S. (eds.). Checklist delle specie della Fauna italiana, 57, Calderini, Bologna

Bologna M.A., 2016 - Range extention of two Oedemeridae species in the Italian peninsula and other faunistic new records (Coleoptera). Bollettino dell'Associazione Romana di Entomologia, 71: 21-25.

Brustel H., KAKiopoulos G., 2009 - Contribution à la connaissance de la faune de Grèce (Coleoptera: Oedemeridae). Biocosme Mésogéen, Nice, 26(2): 65-75.

CuRLETti G., 2005 - Insecta Coleoptera Buprestidae. In: RufFo S., Stoch F. (eds.). Checklist e distribuzione della fauna italiana. Memorie del Museo Civico di Storia Naturale di Verona, 2 serie, Sezione Scienze della Vita 16.

GRIDELLI E., 1950 - Il problema delle specie a diffusione transadriatica, con particolare riguardo ai Coleotteri. Memorie di Biogeografia adriatica, 1:7-299.

Osella G., Magnano L., 1986 - I coleotteri attelabidi e curculionidi a diffusione transadriatica. Biogeographia, 10(1): 701-792.

PezZI G., BendAzZI I., 2010 - Interessanti ritrovamenti entomologici in Romagna (Insecta Orthoptera, Coleoptera, Lepidoptera, Hymenoptera). Quaderno di studi e notizie di storia naturale della Romagna, 31: 31-36.

SAMA G., LöBL I., 2010 - Cerambycidae, Western Palaearctic taxa, eastward to Afghanistan, excluding Oman and Yemen and the countries of the former Soviet Union, pp. 84 -334. In: LöBl I. \& SMETANA A. (eds.). Catalogue of Palaearctic Coleoptera. 6. Chrysomeloidea. Apollo Books, Stenstrup: 924 pp.

ŠvinLA V., 1991 - Contribution to the knowledge of the Old World Oedemeridae (Coleoptera). Annotationes Zoologicae et Botanicae, 202: 1-14.

ŠVIHLA V., 1997 - Contribution to the knowledge of Palaearctic and Oriental Oedemeridae (Coleoptera). Folia Heyrovskyana, 5: 83-96.

ŠviHLA, V., 2008 - New Acts and comments, Oedemeridae, p. 45; Family Oedemeridae, pp. 353-369. In: LöBl I. \& SMETANA A. (eds.). Catalogue of Palaearctic Coleoptera. Vol. 5. Stenstrup: Apollo Books.

VÁzQUEZ X.A., 2002 - European Fauna of Oedemeridae. Argania Editio, Valencia.

VÁsquez X.A., RECALDE J.I., 2003 - Nacerdes (Xanthochroa) carniolica atlantica Allemand, 1993, nueva para la península ibérica (Coleoptera: Oedemeridae). Boletín de la Sociedad Entomológica Aragonesa, 33: 131-133. 